\title{
MODELOVÁ CIRKULACE FLUID V EXPERIMENTÁLNÍ NÁDOBĚ MOCK-UP-CZ
}

\author{
Mathematical modelling of fluid circulation in experimental vessel Mock-Up-CZ
}

\author{
Martin Šrámek, Tomáš Kuchovský
}

Ústav geologických věd PřF MU, Kotlářská 2, 63711 Brno; e-mail: 357647@mail.muni.cz

Key words: Mock-Up-CZ, numerical model, SHEMAT, convection cell

\begin{abstract}
Experiment simulating the storage of spent nuclear fuel in the canister filled by bentonite mixture took place in the Center of experimental Geotechnics (CEG) on the Faculty of Civil engineering of the Czech Technical University in Prague during the years 2002-2006. After the realisation of the experiment it was shown, that both non-homogeneous geochemical and temperature fields were established. The main aim of the work was focused on the evaluation of the fluid flow characteristics inside the container, especially on the direction and flow velocities influenced by the increased temperature. Numerical modelling using the SHEMAT computer code was used to simulate the fluid flow.

Mathematical modelling confirmed the probable formation of the convection cells along the heater with variable velocities depending on the hydraulic and thermal properties of the bentonite mixture and on the physical properties of the saturating fuid. The generated flow field could be the driving force for the geochemical non-homogeneities.
\end{abstract}

Úvod

Ukládání vyhořelého jaderného odpadu je jedním $z$ aktuálně řešených problémů $v$ řadě vyspělých států světa, které disponují jadernou energetikou. V rámci dlouhodobého výzkumu probíhají in-situ experimenty simulující ukládání vyhořelého jaderného odpadu do kontejneru obklopeného inženýrskou a př́rodní bariérou. Jedním z nich byl i experiment Mock-Up-CZ. Cílem práce bylo vytvoření matematického modelu experimentálního kontejneru pro ukládání vyhořelého jaderného odpadu a potvrdit, či popřít vznik konvekčních cel v nádobě. Samotný článek přibližuje modelování v programu SHEMAT, jehož cílem bylo posoudit variabilitu cirkulace fluid $\mathrm{v}$ kontejneru a odhalit její možné přičiny na vznik nehomogenit, které byly zjištěny při dismantlingu. Cirkulace fluid v uzavřeném kontejneru pro deponování vysoce aktivního paliva může vést k zásadnímu ovlivnění vlastností bentonitu i materiálu pláště kontejneru, což může vést až k omezení spolehlivé funkce primárních složek inženýrské bariéry.

\section{Experiment Mock-Up-CZ}

Konstrukce fyzikálního modelu Mock-Up-CZ byla tvořena válcovou ocelovou nádobou s tlouštkou stěny $7,7 \mathrm{~mm}$, vnějším průměrem $800 \mathrm{~mm}$ a výškou $2240 \mathrm{~mm}$. Nádoba byla vsazena do jámy (krychle) o hraně $3 \mathrm{~m}$. Dno nádoby bylo tvořeno ocelovou deskou o tlouštce $50 \mathrm{~mm}$, přivařenou k válcové nádobě. Víko nádoby tlouštky $50 \mathrm{~mm}$ bylo staženo k plášti za pomoci 16 svorníků o ø $22 \mathrm{~mm}$, celá kontaktní plocha byla opatřena těsněním. Systém byl navrhnut pro vnitřní tlak až $5 \mathrm{MPa}$ (Pacovský et al. 2007).

Prostor mezi topným tělesem a ocelovou nádobou byl vyplněn více než třemi sty tvárnicemi o tlouštce $70 \mathrm{~mm}$, tvořenými bentonitovou směsí s příměsí křemenného písku a grafitu. Zbylý prostor byl podle Svobody a Vašička (2010) tvořen montážní spárou o tlouštce $25 \mathrm{~mm}$ vyplněnou vzduchem a $50 \mathrm{~mm}$ vnějším zásypem, vytvořeným ručně zhutněnou směsí s identickým složením jako je složení tvárnic.

Vnitřní strana ocelového pláště byla opatřena zavodňovacím systémem, který umožňoval dlouhodobou hydrataci systému. Jednalo se o 4 perforované trubičky umístěné po $90^{\circ}$ po obvodu válcového tělesa.

Hydratační systém byl oddělen od bentonitové bariéry dvojitou filtrační sítí, která umožňovala rovnoměrné vlhčení bentonitové bariéry (Svoboda - Vašíček 2010).

\section{Metodika}

Hlavním cílem numerického modelování v programu SHEMAT (Bartels et al. 2003) bylo sestrojit model kontejneru experimentální nádoby Mock-Up-CZ a za pomoci programových nástrojů určit a popsat charakteristiku proudění a distribuce teploty uvnitř bentonitové bariéry.

Program SHEMAT využívá k řešení numerických simulací proudění a přenosu tepla základní rovnice pro proudění vycházející z Darcyho zákona pro proudění tekutin v porézním médiu v kartézském koordinačním systému (x, y, z) (Bartes et al. 2003):

$$
\underbrace{\rho_{\mathrm{f}} \mathrm{g}(\alpha+\Phi \beta)}_{\mathrm{S}_{\mathrm{f}}} \frac{\partial \mathrm{h}_{0}}{\partial \mathrm{t}}=\nabla[\underbrace{\frac{\rho_{\mathrm{f}} \mathrm{gk}}{\mu}}_{\mathrm{K}}\left(\nabla \mathrm{h}_{0}+\rho_{\mathrm{r}} \nabla \mathrm{z}\right)]+\underbrace{\mathrm{W}_{\mathrm{s}} \frac{\rho^{*}}{\rho_{0}}}_{\mathrm{W}^{\prime}}
$$

kde $S_{s}$ je výraz pro koeficient specifické storativity, K je tensor hydraulické vodivosti a $\mathrm{W}^{\prime}$ vyjadřuje zdroje či úbytky 
hmotových toků. Zbylé parametry vyjadřují referenční hydraulickou výšku $h_{o}$, relativní hustotu $\rho_{r}$ a z je hloubka.

Teplo může být přenášeno $\mathrm{v}$ saturovaném, porézním prostř̌edí třemi cestami: kondukcí skrz pevnou fázi, kondukcí přes kapalnou fázi, konvekcí a advekcí neboli prouděním kapaliny. Rovnice pro přenos tepla je podobná rovnici proudění tekutin a vychází ze zákona zachování energie (Clauser 1999).

Nedílnou součástí výpočtu je bezrozměrné Pecletovo číslo $\left(\mathrm{P}_{\mathrm{e}}\right)$, které kvantitativně určuje, zda v systému převažuje mechanická disperze či difuze, v tomto př́ípadě jestli dochází $\mathrm{k}$ př̀nosu tepla za pomoci advekce nebo teplotního gradientu. Pecletovo číslo je definováno jako,

$$
\mathrm{P}_{\mathrm{e}}=\frac{\mathrm{Z} \cdot \mathrm{u}}{\mathrm{D}}
$$

kde $\mathrm{Z}$ je délka transportu, u je průtoková rychlost kapalné fáze a $\mathrm{D}$ značí disperzní koeficient. To jestli dojde v systému ke konvekci je dáno hodnotou Rayleighova čísla. Ke konvekci dochází v materiálech, pro které tzv. Rayleighovo číslo Ra nabývá hodnoty větší než 1000 . Rayleighovo číslo může být vyjádřeno jako,

$$
\mathrm{Ra}=\frac{\mathrm{ga} \theta}{\mathrm{vk}} \mathrm{D}^{4}
$$

kde D je tlouštka vrstvy, g tíhové zrychlení, a tepelná roztažnost, $\mathrm{v}$ kinematická viskozita, $\kappa$ tepelná difuzivita, $\theta$ superadiabatický teplotní gradient.

\section{Okrajové podmínky}

V programu SHEMAT (Bartels et al. 2003) nelze nastavit nepropustné hranice uvnitř modelu. Proto, aby veškerá voda injektovaná do modelu vrty simulujícími saturaci vodou zůstávala v bufferu, byly v zóně I, II a III reprezentující ocelovou nádobu (obr. 2), topné těleso a vzduch kolem modelu, nastaveny pórovitost a propustnost na extrémně nízké hodnoty $\left(1 \cdot 10^{-30}\right.$ resp. $\left.1 \cdot 10^{-50}\right)$, které nemohou proudění ovlivnit.
Hydraulický gradient byl řešen tak, aby výsledný rozdíl hydraulických potenciálů zajistil veškerý transport média pomocí difuze. To bylo opakovaně testováno a do modelu byl v tomto prrípadě hydraulický gradient I nastaven na $4,5 \cdot 10^{-11}$. Model byl řešen v režimu ustáleného proudění a při plné saturaci pórů.

Tepelné okrajové podmínky byly nastaveny jako zóny s konstantní teplotou. Topné těleso bylo simulováno jako okrajová podmínka s konstantní teplotou $95^{\circ} \mathrm{C}$. Stejné nastavení bylo použito i pro oblast simulující vzduchový obal na hodnotu $20^{\circ} \mathrm{C}$.

\section{Vstupní parametry do modelování}

Vstupní modelová data byla převzata z literatury zabývající se výše zmíněným experimentem a odborné literatury (tab. 1). Model vychází $\mathrm{z}$ naměřeného rozložení teploty, které se ustálilo během pokusu po úplné saturaci experimentální nádoby vodou (obr. 1). Modelová oblast byla rozdělena do osmi zón na základě hydraulických a tepelných parametrů jednotlivých oblastí (viz. tab. 1). Hydraulické a tepelné parametry bufferu se měnily v závislosti na teplotě, podle vzdálenosti od topného tělesa (hodnota vzdáleností pro zóny IV až VIII je měřena od topného tělesa). Změnu hydraulických parametrů v souvislosti s teplotou zmiňuje např. Push et al. (2007). Rovněž Přikryl - Weisthouptová (2010), kteří se zaměřili na objem, specifikou plochu a poloměr pórů v závislosti na teplotě, přicházejí se stejným závěrem. Okrajové podmínky a geometrie modelu byly zvoleny ve shodě s experimentem (obr. 2), kdy bentonitová bariéra byla rozdělena do pěti zón s odlišnými hydraulickými a tepelnými parametry. Základní velikost modelové buňky byla $1 \times 1 \mathrm{~cm} \mathrm{~s}$ tlouštkou $10 \mathrm{~cm}$.

Vstupní parametry pro injektovanou vodu jsou následující: hustota $\left(998 \mathrm{~kg} / \mathrm{m}^{3}\right)$, tepelná vodivost $(0,60 \mathrm{~W} / \mathrm{m} \cdot \mathrm{K})$, měrná tepelná kapacita $(4187 \mathrm{~J} / \mathrm{kg} \cdot \mathrm{K})$, kompresibilita $\left(4,5 \cdot 10^{-10} \mathrm{~Pa}\right)$ (Bartels et al. 2003).

\section{Výsledky a diskuze}

Výstupem z programu SHEMAT (Bartels et al. 2003) jsou grafy znázorňující rozložení teploty, rychlost proudění ve směru osy X (šiřka experimentální nádoby, obr. 3)

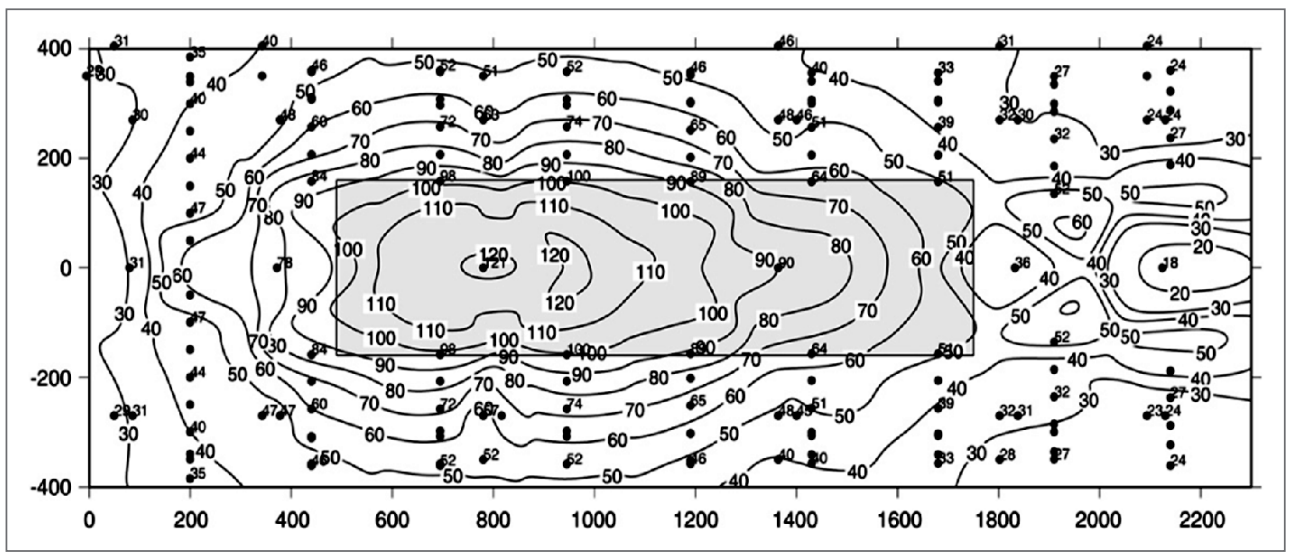

Obr. 1: Rozložení teploty v bentonitové barieře experimentu Mock-Up-CZ; hodnoty na ose $\mathrm{x}$ a y jsou vzdálenosti v mm; numerická data jsou teploty v ${ }^{\circ} \mathrm{C}$ (Přikryl - Weishauptová 2010).

Fig. 1: Distribution of peak temperature in the buffer of the Mock-Up-CZ; the values on $\mathrm{x}$ and $\mathrm{y}$ axes are distances in $\mathrm{mm}$; numerical data within picture are temperatures in ${ }^{\circ} \mathrm{C}$ ( Přikryl - Weishauptová 2010). a rychlost proudění ve směru Z (výška experimentální nádoby, obr. 2). Proudění ve směru X je znázorněno v kladných a záporných hodnotách, kde hodnoty kladné znázorňují proudění do pravé strany a hodnoty záporné naopak do levé strany. Stejný princip je použit pro znázornění proudění ve směru $Z$, kde hodnoty kladné ukazují směr proudění nahoru a hodnoty 
Tab. 1: Vstupní hydraulické a tepelné parametry do programu SHEMAT (Push et al. 2007; Blomberg 2001).

Tab. 1: Input data of hydraulic and thermal properties of the zones in program SHEMAT (Push et al. 2001; Blomberg 2001).

\begin{tabular}{|l|l|c|c|c|c|}
\hline \multirow{2}{*}{} & & \multicolumn{2}{c|}{ Hydraulické parametry } & \multicolumn{2}{c|}{ Tepelné parametry } \\
\cline { 3 - 6 } & $\begin{array}{c}\text { Pórovitost } \\
(\mathrm{n}),(--)\end{array}$ & $\begin{array}{c}\text { Propustnost } \\
(\mathrm{K}),\left(\mathrm{m}^{2}\right)\end{array}$ & $\begin{array}{c}\text { Tepelná } \\
\text { vodivost }(\lambda), \\
(\mathrm{W} / \mathrm{m} \cdot \mathrm{K})\end{array}$ & $\begin{array}{c}\text { Objemová tepelná } \\
\text { kapacita }(\rho \mathrm{c}), \\
\left(\mathrm{J} / \mathrm{cm}^{3} \cdot \mathrm{K}\right)\end{array}$ \\
\hline Zóna I & Vzduch & -- & -- & 0,026 & $1,21 \cdot 10^{-3}$ \\
\hline Zóna II & Ocelová nádoba & -- & -- & 60 & 3,7 \\
\hline Zóna III & Topné těleso $(\mathrm{obal})$ & -- & -- & 60 & 3,7 \\
\hline Zóna IV & Buffer $(22-19 \mathrm{~cm})$ & 0,55 & $9,86 \cdot 10^{-15}$ & 2,25 & 2,4 \\
\hline Zóna V & Buffer $(18-15 \mathrm{~cm})$ & 0,52 & $1,58 \cdot 10^{-13}$ & 2,4 & 2,4 \\
\hline Zóna VI & Buffer $(14-10 \mathrm{~cm})$ & 0,47 & $1,87 \cdot 10^{-13}$ & 2,5 & 2,4 \\
\hline Zóna VII & Buffer $(9-5 \mathrm{~cm})$ & 0,49 & $2,27 \cdot 10^{-12}$ & 2,48 & 2,4 \\
\hline Zóna VIII & Buffer $(4-0 \mathrm{~cm})$ & 0,46 & $2,07 \cdot 10^{-12}$ & 2,57 & 2,4 \\
\hline
\end{tabular}

Ve výšce $145 \mathrm{~cm}$ (E, obr. 4) dojde ke změně směru horizontálního proudění směrem ke středu nádoby, který zesiluje ve výšce $90-100 \mathrm{~cm}$ (C, obr. 4), kde dochází k otáčení směru proudění směrem vzhůru. Podél topného tělesa se rychlost vertikálního proudění směrem vzhůru pohybovala v rozmezí 80 až $1,25 \mathrm{~mm}$ za den na hranici styku proudění směrem dolů. Následně došlo k mírnému stočení proudění podél horního levého rohu topného tělesa směrem $\mathrm{k}$ topnému

záporné pohyb vody směrem dolů. Interpretace naměřených dat vychází $\mathrm{z}$ aplikace základních rovnic proudění a přenosu tepla využivaných programem SHEMAT.

V modelu simulujícím proudění v experimentální nádobě Mock-Up-CZ můžeme vyčlenit dvě konvekční cely v horní části kontejneru zasahující nejméně do dvou horních třetin experimentální nádoby. Tyto dvě cely mají téměř zrcadlovou symetrii dle osy protínající střed kontejneru.

Kladné hodnoty proudění ve směru Z (obr. 3) v horní části nad topným tělesem naznačují pohyb směrem vzhůru k okraji kontejneru (A, obr. 3). Rychlost proudění zde dosahovala hodnoty $25 \mathrm{~mm}$ až $50 \mathrm{~mm}$ za den, směrem k okraji klesá na hranici $1,25 \mathrm{~mm}$ za den, následně se proudění stáčí směrem od topného tělesa ( $B$, obr. 4). V zónách s vyšší propustností (VII, VIII; obr. 2) blíže topnému tělesu byla rychlost proudění ve směru osy $\mathrm{X}$ vyšší, nežli tomu je v zóně s nižší propustností. Tento trend dále pokračuje i ve vertikálním proudění směrem dolů, kdy hodnoty rychlosti proudění jsou nejvyšší v místech náležící zóně VI (obr. 2) s propustností odpovídající hodnotě $1,87 \cdot 10^{-13} \mathrm{~m}^{2}$. Dále $\mathrm{k}$ okraji nádoby se rychlost proudění snižuje až na hodnotu blízkou $1,25 \mathrm{~mm}$ za den. Během vertikálního pohybu směrem ke dnu nádoby byla horizontální složka rychlosti jen do $1,25 \mathrm{~mm}$ za den. tělesu a opět směrem vzhůru. Část toku, která se ve výšce 90-100 cm neotočila a nevracela zpět, pokračuje až k bodu (D, obr. 3) okolo $70 \mathrm{~cm}$ nad dnem nádoby, kde pokračuje ve stejném trendu jako v bodu $\mathrm{C}$.

Data z modelu ukazují, že veškerá voda dostávající se do systému v dolní třetině experimentální nádoby měla tendenci vystupovat vzhưru a to rychlostí odpovídající až 1,25 mm za den. V levém dolním rohu proudění směřuje do středu, kde $\mathrm{v}$ důsledku nehomogenity (zóna $s$ nižší propustností) dochází ke změně směru proudění a ve vzdálenosti $20 \mathrm{~cm}$ od spodní části topného tělesa se obrací směrem k okraji nádoby. Na úrovni topidla se opět stáčí směrem $\mathrm{k}$ topnému tělesu a směřuje do horní části experimentální nádoby rychlostí $5 \mathrm{~mm}$ za den v blízkosti topidla. Identický zrcadlově symetrický jev je pozorován na druhé straně modelu kontejneru.

Z modelování je patrné, že veliký vliv na rychlost proudění mají nejen fyzikální vlastnosti vody, ale i nehomogenity, které patrně vznikly v přípravné fázi fyzikálního experimentálního modelu. $Z$ tensoru hydraulické vodivosti K (rovnice 3.1) je patrné, že při klesající viskozitě vody v závislosti na rostoucí teplotě, roste filtrační (Darcyho) rychlost. Přestože s vyšší teplotou je hustota nižší, ve srovnání se změnou viskozity se jedná o malý rozdíl a výsledná hodnota filtrační rychlosti bude vyšší.

Nehomogenity, které vznikly v samotném začátku fyzikálního experimentu, byly způsobeny pravděpodobně několika dílčími jevy. Samotné experimentální uspořádání ve fyzikálním modelu (tvárnice vyplněné směsí), pravděpodobně vedlo ke vzniku přednostní infiltrace. Př̀i saturaci na frontě smáčení dochází $\mathrm{k}$ transportu ionů rozpuštěných ve vodě, které se sráží a rozpouštějí a pravděpodobně ovlivňují tepelně-hydraulické charakteristiky
Obr. 2: Schématické rozdělení zón ve vertikálním řezu modelu, simulující experiment Mock-Up-CZ.

Fig. 2: Schematic divison of zones in vertical cross- section of model simulating experiment Mock-Up-CZ. 


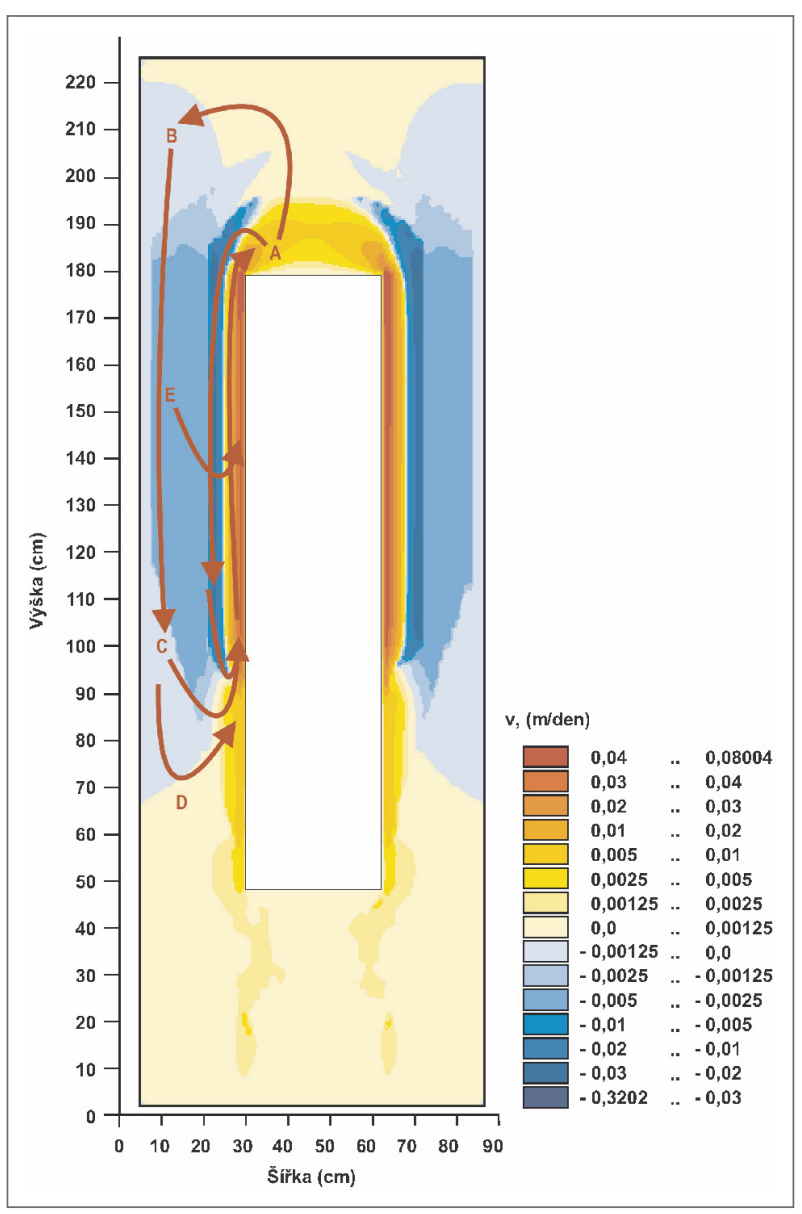

Obr. 3: Rychlost proudění ve směru Z.

Fig. 3: Flow speed in $\mathrm{Z}$ direction.

(Karnland et al. 2009). Dalším jevem podílejícím se na nehomogenitě bufferu, je pokles plochy a celkového objemu pórů, zapř́ičiněný částečným rozpadem jílových agregátů majících rozměr do $3 \mathrm{~mm}$. Poloměr makropórů se zvýšil dvoj- až trojnásobně z $500 \mathrm{~nm}$ na $1500 \mathrm{~nm}$ v zónách s nejvyšší teplotou $\left(85^{\circ} \mathrm{C}\right)$ (Přikryl - Weishauptová 2010).

Vznik konvekčních cel v experimentální nádobě Mock-Up-CZ má pouze teoretický předpoklad a nelze jej experimentálně prokázat. Distribuce tepla je významný faktor a, přestože jej nelze prokázat jinak než teoreticky za pomoci matematického modelování, může se významně podílet na intenzitě geochemických procesů spojených $s$ transformací bentonitu. Dominujícím procesem transportu v kontejneru je difúze vyjádřená Pecletovým č́slem $\mathrm{Pe}$ (rovnice 3.2). Hodnota Rayleighova č́sla $\left(\mathrm{Ra}=1,74 \cdot 10^{-6}\right)$ dopočítána vzorcem (3.3) nedosahuje hodnoty blížící se limitní hranici (kritická hodnota) pro vznik konvekčních cel, která je $\mathrm{Ra}=103$. Podle Kostoglou et al. (2013) závisí velikost kritické hodnoty Rayleighova čísla na podmínkách panujících v systému, ve kterém ke vzniku konvekčních cel došlo. Tudíž nelze vyloučit možný vznik konvekčních cel v bufferu. Míra konvekce narůstá se vzrůstajícím teplotním rozdílem a koeficientem tepelné vodivosti prostředí a klesá se vzrůstající viskozitou a chaotickým pohybem molekul.

Uvedené skutečnosti je potřeba brát $\mathrm{v}$ potaz př̀i hodnocení výsledků numerického modelování. I přes veškerou snahu o dodání nejpřesnějších vstupních dat může

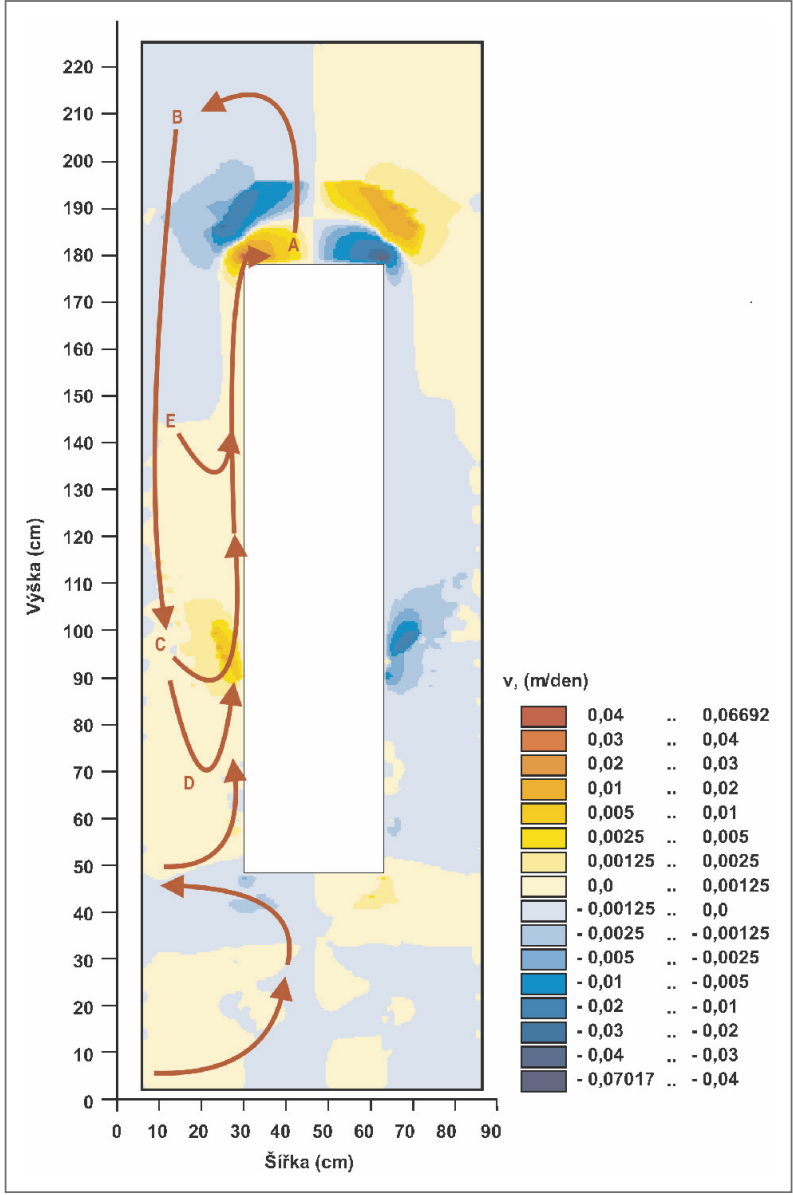

Obr. 4: Rychlost proudění ve směru X.

Fig. 4: Flow speed in $\mathrm{X}$ direction.

být chování konvekčních cel nebo jejich existence uvnitř nádoby odlišná, poněvadž vychází z teplotních podmínek v zadaném poli při zadaných okrajových podmínkách a vlastnostech domény. A to při předpokladu, že by v reálné nádobě opravdu mohlo dojít ke vzniku konvekčních cel.

\section{Závěr}

Znumerického modelování, při zadaných okrajových podmínkách a vlastnostech zón, můžeme uvažovat o vytvoření nehomogenit, kde je rychlost proudění ve směru $\mathrm{Z}$ podél topného tělesa dána především hydraulickými parametry konkrétní nehomogenní zóny. Stejné podmínky platí pro rychlost proudění ve směru X. Dalším faktorem přispívajícím k rozdílným rychlostem proudění jsou fyzikální vlastnosti vody, jako jsou její hustota a viskozita, které se mění s teplotou vody. Při rozebírání fyzikálního modelu byly potvrzeny nehomogenity $\mathrm{v}$ bentonitové bariére. $\mathrm{Zda}$ byly způsobeny v samotném počátku nebo při zahřívání, saturaci či až následně při teoretickém formování konvekčních cel tato práce neřeší. Podle proudění je však jasné, že konvekční cely následně významně ovlivňují geochemické procesy v zónách s vyšší rychlostí proudění a teplotou.

\section{Poděkování}

Autoři článku děkují za konzultace kolegům z pracoviště CEG ČVUT v Praze. Článek vznikl za podpory Projektu OPVK 2.3. - CZ.1.07/2.3.00/20.0052 ReWaNuSa. 


\section{Literatura}

Bartels, J. - Clauser, C. - Kühn, M. (2003): SHEMAT - Simulator for Heat and Mass Transport (verze 7.1) [počítačový program]. - Springer Verlag, Heidelberg-Berlin.

Blomberg, T. (2001): HEAT3 - Three-dimensional heat transfer (manuálk verzi 4.0) [počítačový program] - Blocon Sweden (www. buildingphysics.com), Nordmannavagen 96, SE-224 75 Lund, Sweden.

Bartels, J. - Clauser, C. - Kühn, M. (2003): Numerical Simulation of Reactive Flow using SHEMAT. - In: Clauser C. (ed.), Numerical Simulation of Reactive Flow in Hot Aquifers - SHEMAT/Processing SHEMAT, Springer Verlag, Heidelberg-Berlin, 5-74 .

Clauser, C. (1999): Thermal Signatures of Heat Transfer processes in the Earth's Crust (Lecture Notes in Earth Science), 85. Springer Verlag, Heidelberg-Berlin, 111 str.

Karnland, O. - Olsson, S. - Dueck, A. - Birgersson, M. - Nilsson, U. - Hernan-Hakansson, T. - Pedersen, K. - Nilsson, S. - Eriksen, T-E. - Rosborg, B. (2009): Long-term test of buffer material at the ÄspöHard Rock Laboratory, LOT project. - Final report on the A2 test parcel. SKB TR-09-29, SvenskKärnbränslehantering AB.

Kostoglou, M. - Evgenidis, S. P. - Karapantsios, T. D. (2013): Unexpected natural convection heat transfer for small Rayleigh numbers in external geometry. - International Journal of Heat and Mass Transfer, 64, 773-782. Amsterdam.

Pacovský, J. - Svoboda, J. - Zapletal, L. (2007): Saturation development in the bentonite barrier of the Mock-Up-CZ geotechnical experiment. - Physics and Chemistry of the Earth, 32 (8-14): 767-779.

Přikryl, R. - Weishauptová, Z. (2010): Hierarchical porosity of bentonite-based buffer and its modification due to increased temperature and hydration. - Applied Clay Science, 47 (1-2): 163-170.

Push, R. - Pacovský, J. - Čechová, Z. (2007): Are all smectite clays suitable as "buffer"? - Physics and Chemistry of the Earth, část A/B/C 32 (1-7), 116-122.

Svoboda, J. - Vašíček, R. (2010): Preliminary geotechnical results from the Mock-Up-CZ ex-periment. - Applied Clay Science, 47(1-2): 139-146. 